\title{
Nickel bioaccumulation by the chosen plant species
}

\author{
Jacek Antonkiewicz $^{1}$ - Czesława Jasiewicz ${ }^{1}$ Małgorzata Koncewicz-Baran ${ }^{1}$. \\ Renata Sendor ${ }^{1}$
}

Received: 10 June 2015/Revised: 15 December 2015/ Accepted: 4 January 2016/Published online: 19 January 2016

(c) The Author(s) 2016. This article is published with open access at Springerlink.com

\begin{abstract}
The investigations aimed at the evaluation of nickel bioaccumulation ability of plants from various families (Poaceae-maize, Fabaceae-field bean and Asteraceae-lettuce). The research was conducted under hydroponic conditions. The experimental design comprised ten objects differing with nickel concentrations in the solution (ranging from 0.0 to $10.0 \mathrm{mg} \mathrm{Ni} \mathrm{dm}^{-3}$ of the nutrient solution). The parameters, assumed as the basis on which nickel bioretention by selected plant species was determined were: the yield, nickel content in various plant parts, uptake and utilization of this element by the plant, tolerance index (TI) and translocation factor (TF), the metal concentrations in the aboveground parts index $(\mathrm{CI})$ and bioacummulation factor (BAF). On the basis of the obtained results it was found that, due to low tolerance of nickel, maize could be used as the indicator plant for the environment quality assessment.
\end{abstract}

Keywords Phytoremediation · Yield · Hydroponic cultivation $\cdot$ Heavy metals $\cdot$ Nickel uptake

\section{Introduction}

Human activities, such as natural minerals extraction, processing industries or energy generation and modern agricultural practices have a long lasting harmful impact on the

Communicated by N. A. Anjum.

Jacek Antonkiewicz

rrantonk@cyf-kr.edu.pl

1 Department of Agricultural and Environmental Chemistry, University of Agriculture in Krakow, Avenue of Adam Mickiewicz 21, 31-120 Kraków, Poland environment (Conesa et al. 2006; Park et al. 2011; Tank and Saraf 2009). Heavy metals still raise considerable interest as the substances revealing a negative effect on the environment. Some of these elements, e.g. nickel, in small quantities are necessary for growth and development of living organisms (Chen et al. 2009; Zhao et al. 2008). Literature data indicate the necessity of this element for several microorganism, animal and plant species. In plant organisms, the element is a part of urease metalloenzyme participating in urea hydrolysis (Hussain et al. 2013; Seregin and Kozhevnikova 2006). Nickel is taken up by plants mainly as ion $\left(\mathrm{Ni}^{2+}\right)$, whereas it is much harder absorbed in a chelate form. Process of nickel uptake by some monocotyledonous plants, including wheat, rye and maize, occurs through the root cap (Ma et al. 2009; Rathor et al. 2014).

Nickel and its compounds find wide applications in various industries, therefore spreading of this element in the biosphere may negatively impact the course of physiological and metabolic processes in the organisms leading to imbalance (Ahmad and Ashraf 2011; Hussain et al. 2013). Nickel is the element, greatly mobile in the natural environment. It is easily absorbed by plants to the degree proportional to its soil concentration, until it reaches the toxic level (Guo and Marschner 1995; Kim et al. 2005). Plants developed efficient physiological and biochemical mechanisms of the uptake, translocation and accumulation of microelements, even at their low concentrations. The same mechanisms are also used to absorb toxic substances with chemical properties similar to microelements (Panwar et al. 2002; Subhashini and Swamy 2013; Meers et al. 2005). Plant species and varieties are characterized by a greatly diversified ability for heavy metals accumulation (Ogunkunle et al. 2014; Yang et al. 1996). Learning these regularities is particularly important because of potential utilization of these plants for phytoremediation of soils, 
waters and sediments (Krueger et al. 2013; Panwar et al. 2002; Xiang et al. 2009).

To reach a high efficiency of phytoremediation process, the applied plants should reveal a great potential for the accumulation and tolerance of heavy metals (Kidd et al. 2009; Rascio and Navari-Izzo 2011). The so far known species accumulating considerable amounts of heavy metals are generally characterised by a slow seasonal growth, complicated propagation method and small biomass increment, therefore their efficiency in soil cleaning is insufficient (Bluskov et al. 2005; Boyd 2004; Yang et al. 2005).

The investigations aimed at the evaluation of nickel bioaccumulation ability of crops from various families (Poaceae-maize, Fabaceae-field bean and Asteraceaelettuce), as well as determining their usefulness for phytoremediation.

\section{Materials and methods}

\section{Experimental design}

The studies on determining the plant ability to bioaccumulate nickel were conducted under hydroponic cultures. The species belonging to three different families: maize (Poaceae), 'KB-270' c.v., field bean (Fabaceae), Nadwiślański c.v. and lettuce (Asteraceae), 'Królowa Majowych' c.v. were chosen as the test plants. Their seeds used for the experiment were not dressed. The experiment comprised ten objects: the control and nine levels of nickel concentration in the nutrient solution (Table 1).

\section{Seedling preparation}

The hydroponic experiment was carried out at the Experimental Site of the University of Agriculture in Kraków,

Table 1 Experimental design

\begin{tabular}{lll}
\hline Ni dose & & \\
\hline $\begin{array}{l}\text { Mmol Ni dm } \\
\text { nutrient solution }\end{array}$ & $\begin{array}{l}\text { mg Ni dm } \\
\text { solution }\end{array}$ & $\begin{array}{l}\text { mg Ni growing } \\
\text { container }^{-1}\end{array}$ \\
\hline 0.0000 & 0.0 & 0 \\
0.0085 & 0.5 & 10 \\
0.0425 & 2.5 & 50 \\
0.0850 & 5.0 & 100 \\
0.1275 & 7.5 & 150 \\
0.1360 & 8.0 & 160 \\
0.1445 & 8.5 & 170 \\
0.1530 & 9.0 & 180 \\
0.1615 & 9.5 & 190 \\
0.1700 & 10.0 & 200 \\
\hline
\end{tabular}

Poland, and protected from rainfall and pests. After plant seeds germination on Petri dishes, they were planted to plastic seedling trays filled with river sand. To eliminate chemical contamination, the sand had been first washed with hydrochloric acid (20\%) and rinsed several times with tap and distilled water. Seed planting into the substratum prepared in this way aimed to obtain seedlings with low nickel concentration and microbiologically pure. The substratum moisture content during the period of seedling preparation was maintained on the level of $50 \%$ of the maximum water capacity. Water losses were supplemented with redistilled water. Maize seedlings were taken out of the substratum under a water stream to avoid damage of the root system.

When the plants: maize, field bean and lettuce reached the appropriate size (the 3rd leaf stage), they were moved to growing container filled with $20 \mathrm{dm}^{3}$ of clean redistilled water, to enable their adaptation to water conditions. Eight plants were placed in each growing container. For each variant four replicates were conducted.

\section{Experimental conditions}

On the third day after the test plants removal to growing container, the nutrient solution (modified Hoagland solution) was added containing macro- and microelements (in $\mathrm{mg} \mathrm{dm}{ }^{-3}$ ) necessary for the plant growth and development: $\mathrm{Ca}\left(\mathrm{NO}_{3}\right)_{2} \cdot 4 \mathrm{H}_{2} \mathrm{O}-240.00(1 \mathrm{mM}), \mathrm{KNO}_{3}-10.00$ $(0.1 \mathrm{mM}), \quad \mathrm{KH}_{2} \mathrm{PO}_{4}-7.00 \quad(0.05 \mathrm{mM}), \quad \mathrm{KCl}-4.00$ $(0.05 \mathrm{mM}), \quad \mathrm{MgSO}_{4} \cdot 7 \mathrm{H}_{2} \mathrm{O}-100.00 \quad(0.4 \mathrm{mM}), \quad \mathrm{FeSO}_{4-}$ $7 \mathrm{H}_{2} \mathrm{O}-100.00 \quad(0.36 \mathrm{mM}), \quad \mathrm{CuSO}_{4} \cdot 5 \mathrm{H}_{2} \mathrm{O}-0.5 \quad(2 \mu \mathrm{M})$, $\mathrm{H}_{3} \mathrm{BO}_{3}-0.12(2.4 \mu \mathrm{M}), \quad \mathrm{MnSO}_{4} \cdot \mathrm{H}_{2} \mathrm{O}-0.25 \quad(3 \mu \mathrm{M})$, $\mathrm{ZnSO}_{4} \cdot 7 \mathrm{H}_{2} \mathrm{O}-0.10(0.35 \mu \mathrm{M})$, and $\mathrm{Na}_{2} \mathrm{MoO}_{4} \cdot 2 \mathrm{H}_{2} \mathrm{O}-$ $0.10(0.23 \mu \mathrm{M})$. Prepared nutrient solution contained macroelements (in $\mathrm{mg} \mathrm{dm}^{-3}$ ): $\mathrm{N}-15.2, \mathrm{P}-1.6, \mathrm{~K}-8.0$, $\mathrm{Ca}$-40.7, $\mathrm{Mg}-50.5, \mathrm{~S}-24.7$, and microelements (in $\left.\mu \mathrm{g} \mathrm{dm}^{-3}\right): \mathrm{Cu}-127.0, \mathrm{~B}-20.9, \mathrm{Mn}-81.3, \mathrm{Zn}-227.0$, $\mathrm{Mo}-22.3$, Na-5.35. From this moment the nutrient solution (NPK + microelements) was exchanged about every 10 days and iron was supplemented every 4 days. The water level in the containers was checked constantly. The nutrient solution was constantly aerated throughout the period of the experiment. The hydroponic experiment was conducted with a duration of day/night of $15.5 / 8.5 \mathrm{~h}$, an average temperature of $28.0^{\circ} \mathrm{C}$ during the day and $21.0^{\circ} \mathrm{C}$ during the night, an average humidity of $91.0 \%$ and average irradiance of $389.5 \mathrm{~W} \mathrm{~m}^{-2}$.

Four weeks after maize removal to the growing container, 3 weeks after field bean placing there and 2 weeks after lettuce placing, when the plants developed typical aquatic root systems, nickel was added to the growing containers as water soluble salt $-\mathrm{NiNO}_{3}$, in the amounts stated in Table 1.

The plants were harvested before flowering period (maize after 8 weeks, field bean and lettuce after 6 weeks 
of vegetation). During the harvest, roots and the aboveground parts were separated, and for maize and field bean also leaves and stems.

After the harvest the test plant roots were washed several times with distilled water. The plant material was dried to constant weight in a dryer with forced air circulation at the temperature of $70{ }^{\circ} \mathrm{C}$ and the yield of individual plant parts was determined. Dried biomass was crushed in a laboratory mill to prepare it for chemical analyses. Nickel content was determined after the sample mineralization in chamber furnace $\left(450{ }^{\circ} \mathrm{C}\right.$ for $\left.5 \mathrm{~h}\right)$ and dissolving the remains in diluted (1:2) nitric acid, using atomic absorption spectrophotometry method on Philips PU 9100X apparatus (Ostrowska et al. 1991; Kusznierewicz et al. 2012). Content of nickel in plants above ground parts was calculated as a weighted mean of contents of nickel in leaves and stems. Total content of nickel in whole plants was calculated as a weighted mean of contents of nickel in leaves, stems and roots.

A one-factor analysis of variance was conducted for the obtained results in totally randomised design using $f$-Fischer test. The significance of differences between arithmetic means was verified on the basis of homogenous groups determined by Duncan test on the significance level $\leq 0.05$. All statistical computations and selected graphic presentations of results were made using Statistica 10.0 software (Statsoft Poland).

The following parameters were assumed as the basis for nickel tolerance by the tested plant species:

1. Yield.

2. Tolerance index (TI)—defined as the ratio of the plant yield growing on the substratum polluted with nickel and the yield from the control objects, unpolluted with this element (Murphy and Tayz 1995).

3. Nickel content in the individual plant parts.

4. Translocation factor (TF) - which is the ratio of nickel concentrations in the aboveground parts, computed as a weighted average and this element content in roots (Ghosh and Singh 2005; Marchiol et al. 2004).

5. Ni concentration index (CI) in the aboveground parts, computed as a ratio of nickel content in the plant shoots from objects polluted with nickel to its concentrations in the plants from the control object (Mackay and Fraser 2000).

6. Nickel uptake by plants-calculated as a product of dry mass yield and the element content.

7. Nickel utilization by plants-expressed as the share of nickel amount absorbed by the plant in the total nickel amount supplied to the growing containers.

8. Bioaccumulation factor (BAF) - computed as a ratio of nickel content in plant to its concentration in the solution (Ruus et al. 2005; Mackay and Fraser 2000).

\section{Results}

\section{Observations during the plants vegetation}

Symptoms of nickel phytotoxic effect on plants were observed during the experiment already at the $5.0 \mathrm{mg}$ $\mathrm{Ni} \mathrm{dm}^{-3}$ concentration. On the plant aboveground parts, the symptoms of nickel toxic effect were chloroses, necroses and browning, or even blackening at higher doses of nickel which usually resulted in leaves drying. With increasing nickel dose the above-mentioned symptoms were intensifying. In case of roots, the symptoms of nickel toxic effect were a change in the root colouring (brown colour) and inhibition of growth. In effect of the inhibition of the main root and lateral roots elongation, the morphology of root system changed and the effect was more pronounced at higher nickel doses in the nutrient solution.

\section{Plant yield and tolerance index (TI)}

Yield of the test plants depended on the species, its analysed part and nickel concentration in the nutrient solution (Table 2). The highest yields of maize and field bean, irrespectively of the plant part, were obtained from the control. In the other objects, the yields of maize and field bean decreased, in comparison to the control, by increasing $\mathrm{Ni}$ concentrations in the nutrient solution. At lower nickel concentrations in the nutrient solution the yield decrease of individual maize and field bean parts was more visible than at higher doses. The concentration of $0.5 \mathrm{mg} \mathrm{Ni} \mathrm{dm}^{-3}$ caused a $25 \%$ decrease in maize leaves yield and $30 \%$ in the root yield in comparison with the control. In case of field bean, the concentration of $0.5 \mathrm{mg} \mathrm{Ni} \mathrm{dm}{ }^{-3}$ did not cause such a great reduction in yield in comparison with the control. The yield of field bean leaves obtained on this object was lower by $12 \%$, while stem yield by $6 \%$ and root yield by $5 \%$ in comparison with the control. Diminishing of the aboveground parts yield on the object at the highest nickel pollution level $\left(10.0 \mathrm{mg} \mathrm{Ni} \mathrm{dm}^{-3}\right)$ in comparison to the control for maize and field bean was, respectively: for leaves 77 and $67 \%$; for stems 85 and $50 \%$ and for roots 76 and $68 \%$.

The values of tolerance index (TI) for maize and field bean yield assumed values below one (Fig. 1). Values of this index were lowering systematically with increasing nickel concentration in the nutrient solution. Analysing the values of tolerance index (TI) including the cumulative yield, maize may be regarded as the species less tolerant to the applied nickel concentrations in comparison with field bean (Fig. 1). It should be pointed out that the values of this parameter for both plants did not undergo any major 
Table 2 Yield of maize, field bean and lettuce $\left(\mathrm{g}\right.$ growing container ${ }^{-1}$ )

\begin{tabular}{|c|c|c|c|c|c|c|c|c|c|c|c|c|c|}
\hline \multirow[t]{2}{*}{$\begin{array}{l}\text { Ni dose } \\
\left(\mathrm{mg} \mathrm{Ni} \mathrm{dm}^{-3}\right)\end{array}$} & \multicolumn{5}{|c|}{ Maize Zea mays $L$. } & \multicolumn{5}{|c|}{ Field bean Vicia faba L. (partim) } & \multicolumn{3}{|c|}{$\begin{array}{l}\text { Lettuce Lactuca sativa } \mathrm{L} \text {. } \\
\text { var. capitata }\end{array}$} \\
\hline & Leaves & Stems & $\begin{array}{l}\text { Above } \\
\text { ground } \\
\text { parts }\end{array}$ & Roots & Total & Leaves & Stems & $\begin{array}{l}\text { Above } \\
\text { ground } \\
\text { parts }\end{array}$ & Roots & Total & $\begin{array}{l}\text { Above } \\
\text { ground } \\
\text { parts }\end{array}$ & Roots & Total \\
\hline 0 & $81.1^{\mathrm{h}^{*}}$ & $72.8^{\mathrm{e}}$ & $153.9^{\mathrm{g}}$ & $35.5^{\mathrm{e}}$ & $189.4^{\mathrm{g}}$ & $24.9^{\mathrm{f}}$ & $16.2^{\mathrm{e}}$ & $41.1^{\mathrm{e}}$ & $20.3^{\mathrm{e}}$ & $61.4^{\mathrm{d}}$ & $7.4^{\mathrm{b}}$ & $2.4^{\mathrm{ab}}$ & $9.8^{\mathrm{b}}$ \\
\hline 0.5 & $60.5^{\mathrm{g}}$ & $51.4^{\mathrm{d}}$ & $111.9^{\mathrm{f}}$ & $24.9^{\mathrm{d}}$ & $136.8^{\mathrm{f}}$ & $21.9^{\mathrm{e}}$ & $15.3^{\mathrm{e}}$ & $37.2^{\mathrm{d}}$ & $19.3^{\mathrm{e}}$ & $56.5^{\mathrm{c}}$ & $7.4^{\mathrm{b}}$ & $3.0^{\mathrm{bcd}}$ & $10.4^{\mathrm{b}}$ \\
\hline 2.5 & $40.9^{\mathrm{f}}$ & $27.4^{\mathrm{c}}$ & $68.3^{\mathrm{e}}$ & $15.0^{\mathrm{c}}$ & $83.3^{\mathrm{e}}$ & $13.3^{\mathrm{d}}$ & $11.7^{\mathrm{d}}$ & $25.0^{\mathrm{c}}$ & $9.1^{\mathrm{d}}$ & $34.1^{\mathrm{b}}$ & $10.6^{\mathrm{d}}$ & $3.1^{\mathrm{cd}}$ & $13.7^{\mathrm{d}}$ \\
\hline 5.0 & $35.2^{\mathrm{e}}$ & $25.3^{\mathrm{c}}$ & $60.5^{\mathrm{d}}$ & $13.5^{\mathrm{bc}}$ & $74.0^{\mathrm{d}}$ & $12.0^{\mathrm{cd}}$ & $10.2^{\text {cd }}$ & $22.2^{\mathrm{b}}$ & $7.4^{\mathrm{abc}}$ & $29.6^{\mathrm{ab}}$ & $10.9^{\mathrm{d}}$ & $3.4^{\mathrm{d}}$ & $14.3^{\mathrm{d}}$ \\
\hline 7.5 & $28.8^{\mathrm{d}}$ & $13.5^{\mathrm{ab}}$ & $42.3^{\mathrm{c}}$ & $12.6^{\mathrm{b}}$ & $54.9^{\mathrm{c}}$ & $10.6^{\mathrm{bc}}$ & $10.0^{\mathrm{bc}}$ & $20.6^{\mathrm{b}}$ & $8.1^{\mathrm{cd}}$ & $28.7^{\mathrm{ab}}$ & $10.4^{\mathrm{d}}$ & $2.8^{\mathrm{bcd}}$ & $13.2^{\mathrm{d}}$ \\
\hline 8.0 & $24.2^{\mathrm{c}}$ & $14.4^{\mathrm{b}}$ & $38.6^{\mathrm{bc}}$ & $11.9^{\mathrm{b}}$ & $51.5^{\mathrm{c}}$ & $10.9^{\mathrm{bc}}$ & $10.8^{\mathrm{cd}}$ & $21.7^{\mathrm{b}}$ & $8.2^{\mathrm{cd}}$ & $29.9^{\mathrm{ab}}$ & $10.2^{\mathrm{d}}$ & $3.1^{\mathrm{cd}}$ & $13.3^{\mathrm{d}}$ \\
\hline 8.5 & $23.8^{\mathrm{bc}}$ & $12.0^{\mathrm{a}}$ & $35.8^{\mathrm{bc}}$ & $10.3^{\mathrm{a}}$ & $46.1^{\mathrm{b}}$ & $9.6^{\mathrm{ab}}$ & $8.3^{\mathrm{ab}}$ & $17.9^{\mathrm{a}}$ & $6.8^{\mathrm{ab}}$ & $24.7^{\mathrm{a}}$ & $8.9^{c}$ & $2.9^{\mathrm{bcd}}$ & $11.8^{\mathrm{c}}$ \\
\hline 9.0 & $23.0^{\mathrm{bc}}$ & $12.1^{\mathrm{a}}$ & $35.1^{\mathrm{b}}$ & $9.7^{\mathrm{a}}$ & $44.8^{\mathrm{b}}$ & $8.9^{\mathrm{a}}$ & $8.3^{\mathrm{ab}}$ & $17.2^{\mathrm{a}}$ & $6.4^{\mathrm{a}}$ & $23.6^{\mathrm{a}}$ & $7.8^{\mathrm{b}}$ & $2.8^{\mathrm{bcd}}$ & $10.6^{\mathrm{bc}}$ \\
\hline 9.5 & $21.3^{\mathrm{b}}$ & $11.6^{\mathrm{a}}$ & $32.9^{\mathrm{ab}}$ & $8.7^{\mathrm{a}}$ & $41.6^{\mathrm{ab}}$ & $8.9^{\mathrm{a}}$ & $8.5^{\mathrm{ab}}$ & $17.4^{\mathrm{a}}$ & $6.4^{\mathrm{a}}$ & $23.8^{\mathrm{a}}$ & $6.0^{\mathrm{a}}$ & $2.1^{\mathrm{a}}$ & $8.1^{\mathrm{a}}$ \\
\hline 10.0 & $18.8^{\mathrm{a}}$ & $11.3^{\mathrm{a}}$ & $30.1^{\mathrm{a}}$ & $9.0^{\mathrm{a}}$ & $39.1^{\mathrm{a}}$ & $8.3^{\mathrm{a}}$ & $8.1^{\mathrm{a}}$ & $16.4^{\mathrm{a}}$ & $6.5^{\mathrm{a}}$ & $22.9^{\mathrm{a}}$ & $5.7^{\mathrm{a}}$ & $2.0^{\mathrm{a}}$ & $7.7^{\mathrm{a}}$ \\
\hline
\end{tabular}

* Means followed by the same letters in columns did not differ significantly at $p<0.05$ according to the Duncan test

changes within the concentrations range of $5.0-10.0 \mathrm{mg}$ Ni $\mathrm{dm}^{-3}$.

A different dependence, as compared with maize and field bean, was noted for lettuce. Nickel doses ranging from 0.5 to $9.0 \mathrm{mg} \mathrm{dm}^{-3}$ revealed a stimulating effect on the quantity of both the aboveground parts and roots yield in comparison with the control (Table 2). The values of tolerance index for the plants from these objects were from 1.067 to 1.470 (Fig. 1). Only at the concentrations of 9.5

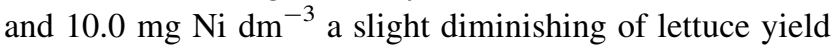
was observed and in result also values of tolerance index decreased (average value 0.815 ).

A significant indicator is changes in the structure of the analysed plant yield elements. Increase in the share of mass of maize leaves and roots in total yield was observed with increasing nickel concentrations in the nutrient solution, whereas a decrease was noted for stem yield share (Table 2). For maize the leaves yield constituted from $43 \%$ (control) to $52 \%\left(8.5 \mathrm{mg} \mathrm{Ni} \mathrm{dm}{ }^{-3}\right)$, stem yield from $25 \%\left(9.5 \mathrm{mg} \mathrm{Ni} \mathrm{dm}^{-3}\right)$ to $38 \%$ (the control and $0.5 \mathrm{mg}$
$\mathrm{Ni} \mathrm{dm}{ }^{-3}$ ), whereas for the roots from $19 \%$ (the control) to $24 \%\left(8.0 \mathrm{mg} \mathrm{Ni} \mathrm{dm}^{-3}\right)$ of the total maize yield. Different relationships were registered for field bean, for which a reduction in the share of the mass of leaves (by $5 \%$ ) and roots (by $8 \%$ ), while the increase in stem mass share (by $9 \%$ ) in the total yield was noticed with increasing nickel concentrations in the nutrient solution in comparison with the control without nickel addition. Growing doses of nickel applied in the experiment did not have any distinctive effect on lettuce yield structure (Table 2).

\section{Nickel contents in plants and values of translocation factor (TF) and nickel concentration index (CI) in the aboveground parts}

Nickel content in plants depended on the species, analysed plant part and this element concentration in the nutrient solution, and ranged from 1.0 to $5826.3 \mathrm{mg} \mathrm{Ni} \mathrm{kg}^{-1} \mathrm{~m}$ (Table 3). The increase in nickel content in the nutrient solution was visible as the growing contents of this element
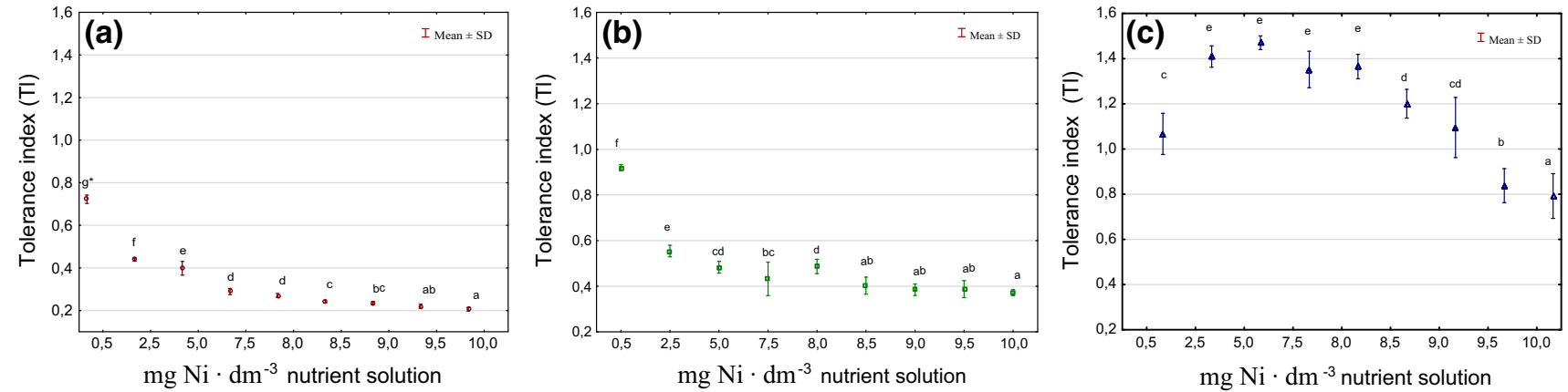

Fig. 1 Values of the yield tolerance index (TI) for the test plants: a maize, $\mathbf{b}$ field bean, $\mathbf{c}$ lettuce. Means followed by the same letters in columns did not differ significantly at $p<0.05$ according to the Duncan test 
in plants. The smallest nickel contents were registered in maize, irrespectively of the analysed organ and the highest in field bean root. In the roots of all plants higher concentrations of this element were noticed in comparison with the aboveground parts. Almost twice the higher nickel contents were found in field bean and lettuce aboveground parts in comparison with maize.

While analysing the relationships between plant yielding and nickel content in their aboveground parts and roots, it may be noticed that in case of maize and field bean a depression in yield occurred already at the first dose of nickel, i.e. $0.5 \mathrm{mg} \mathrm{Ni} \mathrm{dm}^{-3}$, however, in maize a decline in yield was greater. The nickel content in maize aboveground parts was $2.2 \mathrm{mg} \mathrm{kg}^{-1} \mathrm{dm}$, and in roots $293.8 \mathrm{mg} \mathrm{kg}^{-1} \mathrm{dm}$. For field bean the contents of nickel, at which a decline in yield was noted, were much higher, respectively, 26.7 and $455.6 \mathrm{mg} \mathrm{Ni} \mathrm{kg}{ }^{-1} \mathrm{dm}$. In case of lettuce, a decreasing yield in comparison with the control was registered only at the content of $218.7 \mathrm{mg} \mathrm{Ni} \mathrm{kg}^{-1} \mathrm{dm}$ in the aboveground parts and $251.1 \mathrm{mg} \mathrm{Ni} \mathrm{kg}^{-1} \mathrm{dm}$ in roots $\left(9.5 \mathrm{Ni} \mathrm{dm}^{-3}\right)$.

The parameter determining the relationship between nickel content in the aboveground parts and its concentration in roots is the metal TF (Ghosh and Singh 2005; Marchiol et al. 2004). The highest values of this parameter, irrespectively of nickel concentration in the nutrient solution solution, were registered for lettuce, whereas average value of TF for this plant was 0.090 (Fig. 2). Almost twice the lower values of TF index were noted in maize, whereas the lowest values of this parameter were determined for field bean (average value $\mathrm{TF}=0.028$; Fig. 2). In all plants, a decrease in nickel translocation was noted for the control already at its lowest concentration in the nutrient solution $\left(0.5 \mathrm{mg} \mathrm{Ni} \mathrm{dm}{ }^{-3}\right)$, which points to the efficiency of this element retention mechanisms in the plant root system. The analysis of the TF values within the range of the applied nickel concentrations in the nutrient solution $\left(0.5-10.0 \mathrm{mg} \mathrm{dm}^{-3}\right)$ allows to observe two trends: the first of a dynamic increase in TF values for maize within nickel concentration range from 0.5 to $7.5 \mathrm{mg} \mathrm{dm}^{-3}$ and for lettuce from 0.5 to $5.0 \mathrm{mg} \mathrm{dm}^{-3}$, and the second trend concerning TF stabilization for field bean above the mentioned concentrations. No statistically significant differences in this parameter values were observed for field bean within the range of nickel concentrations in the nutrient solution (Fig. 2).

Nickel CI was computed to compare the effect of nickel doses on this element accumulation in the plant aboveground parts in comparison to the plants from the control object unpolluted with nickel (Mackay and Fraser 2000). On the basis of the analysis of this parameter value it may be concluded that among the studied plants, field bean revealed the highest ability to resist nickel

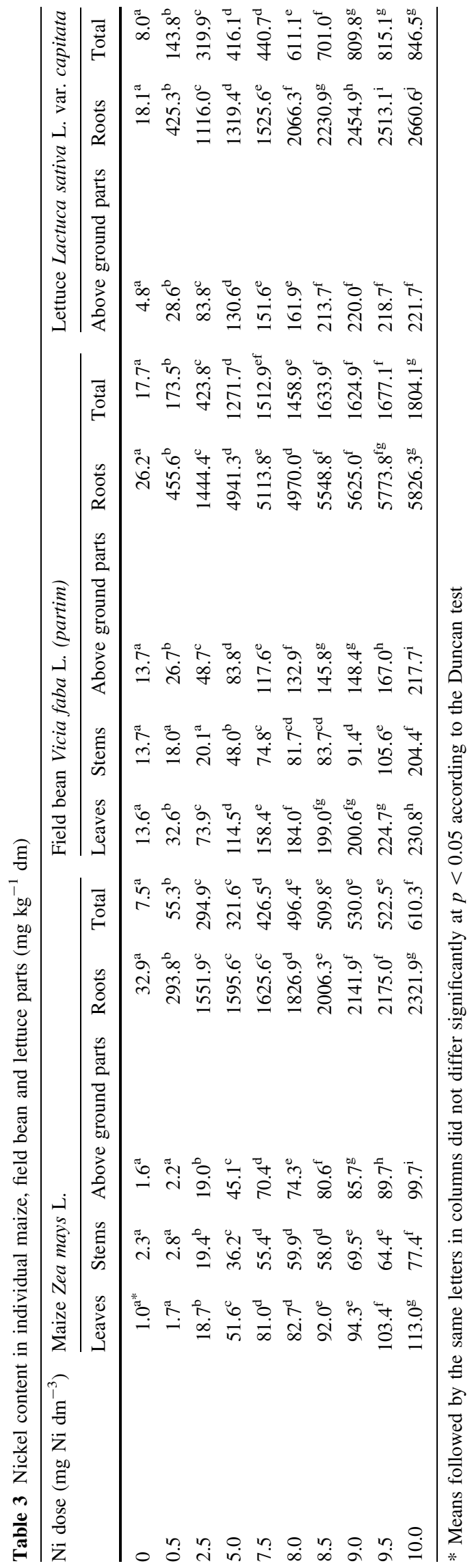



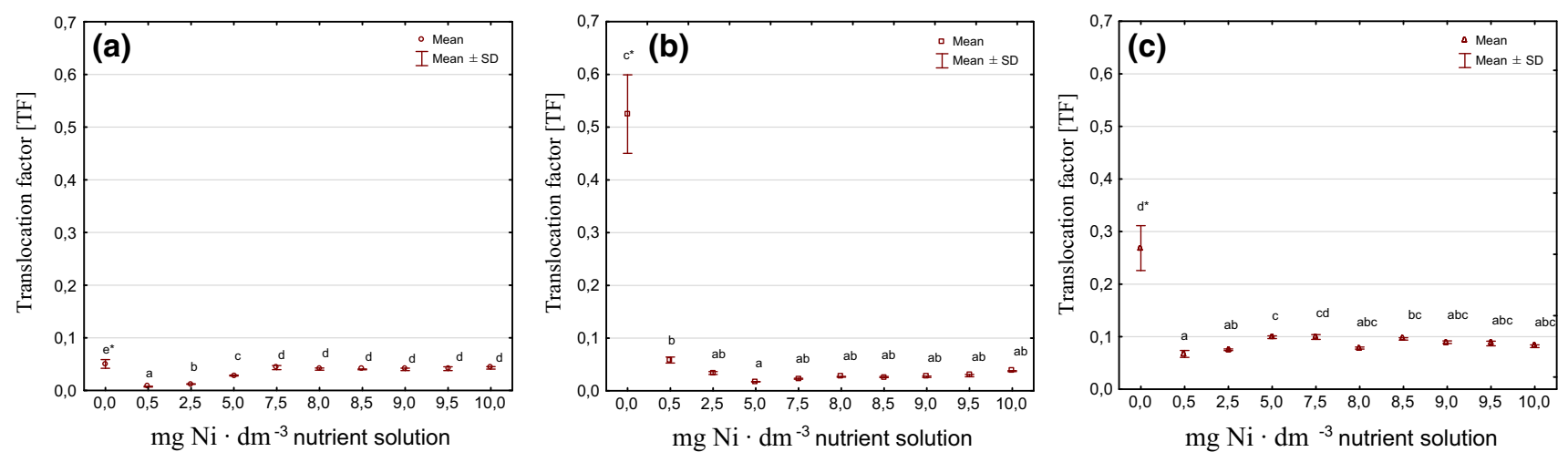

Fig. 2 Values of translocation factor (TF) of nickel in maize (a), field bean (b) and lettuce (c). Means followed by the same letters in columns did not differ significantly at $p<0.05$ according to the Duncan test

accumulation in the aboveground parts. Values of nickel CI for this plant were on average fourfold lower in comparison with maize and lettuce (Fig. 3). The values of CI index were increasing with growing nickel

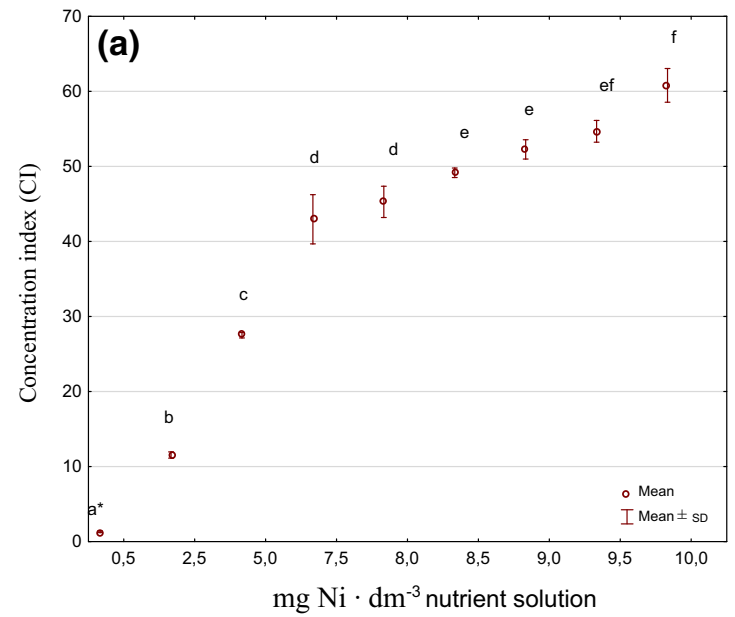

concentration in the nutrient solution, whereas in maize and lettuce at the dose of $8.5 \mathrm{mg} \mathrm{dm}^{-3}$ and higher, generally no statistically significant differences in this parameter value were registered.

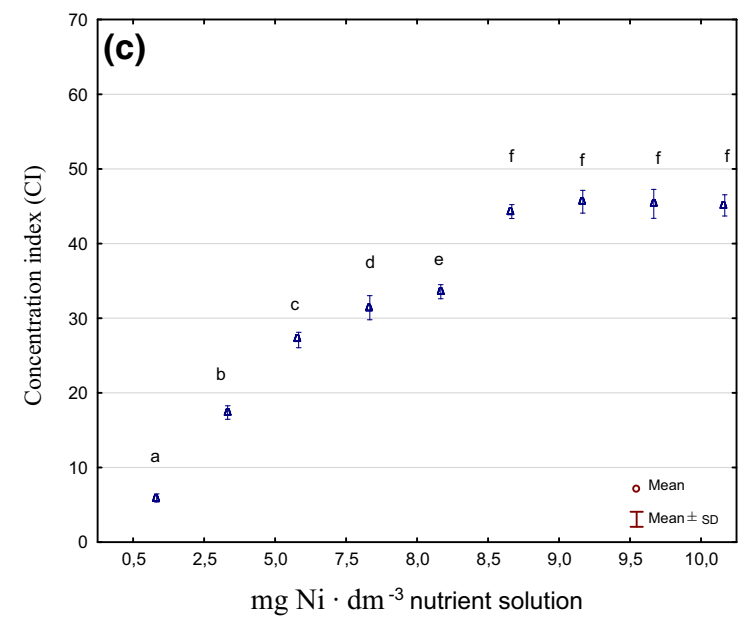

Fig. 3 Values of nickel concentration index (CI) in the aboveground parts of maize (a), field bean (b) and lettuce (c). Means followed by the same letters in columns did not differ significantly at $p<0.05$ according to the Duncan test 
Nickel uptake and utilization by plants, and bioaccumulation factor (BAF)

The lowest for all tested plants nickel uptake was noted at the concentration of $0.5 \mathrm{mg} \mathrm{Ni} \mathrm{dm}{ }^{-3}$ of nutrient solution (Table 4). At the concentrations exceeding $5.0 \mathrm{Ni} \mathrm{dm}{ }^{-3}$ of nutrient solution, the absorbed amounts were diversified, ranging from 22 to $25 \mathrm{mg} \mathrm{Ni}$ growing container ${ }^{-1}$ for maize, $38-44 \mathrm{mg} \mathrm{Ni}$ growing container ${ }^{-1}$ for field bean and 6-9 mg Ni growing container ${ }^{-1}$ for lettuce. In case of maize and field bean, despite the depression in yielding, the quantities of absorbed nickel were higher, which resulted from the increase in this element concentration in the plant biomass. Considering the tested plant species, maize absorbed the highest nickel amounts from the nutrient solution, which results from big yielding potential (Table 2).

Nickel utilization was dependent on the plant species, it yield and this element content in the plant biomass (Table 4). Plants utilized the greatest quantities of nickel at its lowest concentrations in the nutrient solution (maize $76 \%$, field bean $98 \%$ and lettuce $15 \%$ ). On the other hand, the concentration of $7.5 \mathrm{mg} \mathrm{Ni} \mathrm{dm}{ }^{-3}$ and higher did not affect the diversification of this element utilization by plants, which was average for maize $13 \%$, for field bean $23 \%$ and for lettuce $4.5 \%$.

The values of nickel BAF were significantly diversified depending on the plant species-the lowest values of this parameter were noted for maize, whereas for field bean and lettuce the values were, respectively, twice and three times higher (Fig. 4). In all plants, the highest bioaccumulation of nickel was registered at its lowest concentrations in the nutrient solution, i.e. $0.5 \mathrm{~g} \mathrm{Ni} \mathrm{dm}^{-3}$, whereas at the concentration of $5.0 \mathrm{mg} \mathrm{Ni} \mathrm{dm}{ }^{-3}$ and higher, no more differences were noted in this parameter value (Fig. 4).

From among the tested plants, the highest values of BAF were noted for field bean, while the lowest for maize. The highest nickel bioaccumulation in all plants was observed at the concentrations from 0.5 to $5.0 \mathrm{mg} \mathrm{Ni} \mathrm{dm}{ }^{-3}$ of the nutrient solution. At the concentrations exceeding $5.0 \mathrm{mg}$ $\mathrm{Ni} \mathrm{dm}^{-3}$ the parameter values were markedly lower. No statistical diversification of BAF was observed, either in the test plants from these objects. This regularity indicates the presence of defense mechanisms on the cell level protecting the plant against an excessive metal accumulation.

\section{Discussion}

Phytoremediation uses the natural ability of selected plant species for growth and development in the ecosystems polluted with organic and inorganic substances, as well as their uptake and detoxification (Cunningham et al. 1995; Robinson et al. 2003; Neugschwandtner et al. 2008). Research conducted by many authors revealed that some plant species, owing to their specific features, have the ability to absorb and degrade xenobiotics polluting the environment through their active impact on physical, chemical and biological processes occurring in nature, changing them to enable their own life cycle to take place. Moreover, these plants possess defense mechanisms, absorbing, metabolizing and/or concentrating toxic substances in their own tissues and in this way cleaning the environment (Padmavathiamma and Li 2007; Ramamurthy and Memarian 2012; Miguel et al. 2013).

Table 4 Uptake (mg Ni growing container ${ }^{-1}$ ) and utilization of nickel by maize, field bean and lettuce

\begin{tabular}{|c|c|c|c|c|c|c|}
\hline \multirow{3}{*}{$\begin{array}{l}\text { Ni dose }(\mathrm{mg} \\
\left.\text { Ni } \mathrm{dm}^{-3}\right)\end{array}$} & \multicolumn{3}{|c|}{ Uptake of $\mathrm{Ni}$} & \multicolumn{3}{|c|}{ Utilization of $\mathrm{Ni}$} \\
\hline & \multicolumn{3}{|c|}{ mg Ni growing container ${ }^{-1}$} & \multicolumn{3}{|l|}{$\%$} \\
\hline & $\begin{array}{l}\text { Maize Zea } \\
\text { mays L. }\end{array}$ & $\begin{array}{l}\text { Field bean Vicia } \\
\text { faba L. (partim) }\end{array}$ & $\begin{array}{l}\text { Lettuce Lactuca sativa } \\
\text { L. var. capitata }\end{array}$ & $\begin{array}{l}\text { Maize Zea } \\
\text { mays L. }\end{array}$ & $\begin{array}{l}\text { Field bean Vicia } \\
\text { faba L. (partim) }\end{array}$ & $\begin{array}{l}\text { Lettuce Lactuca sativa } \\
\text { L. var. capitata }\end{array}$ \\
\hline 0.0 & $1.42^{\mathrm{a}^{*}}$ & $1.09^{\mathrm{a}}$ & $0.08^{\mathrm{a}}$ & $0.00^{\mathrm{a}}$ & $0.00^{\mathrm{a}}$ & $0.00^{\mathrm{a}}$ \\
\hline 0.5 & $7.57^{\mathrm{b}}$ & $9.80^{\mathrm{ab}}$ & $1.50^{\mathrm{b}}$ & $75.74^{\mathrm{e}}$ & $97.99^{\mathrm{d}}$ & $14.96^{\mathrm{f}}$ \\
\hline 2.5 & $24.52^{\mathrm{cd}}$ & $14.39^{\mathrm{b}}$ & $4.38^{\mathrm{c}}$ & $49.04^{\mathrm{d}}$ & $28.78^{\mathrm{c}}$ & $8.76^{\mathrm{e}}$ \\
\hline 5.0 & $24.35^{\mathrm{cd}}$ & $37.78^{\mathrm{c}}$ & $5.94^{\mathrm{d}}$ & $24.35^{\mathrm{c}}$ & $37.78^{\mathrm{c}}$ & $5.94^{\mathrm{d}}$ \\
\hline 7.5 & $23.49^{\mathrm{cd}}$ & $43.42^{\mathrm{d}}$ & $5.80^{\mathrm{d}}$ & $15.66^{\mathrm{b}}$ & $28.96^{\mathrm{c}}$ & $3.86^{\mathrm{b}}$ \\
\hline 8.0 & $25.50^{\mathrm{d}}$ & $43.53^{\mathrm{d}}$ & $8.10^{\mathrm{e}}$ & $15.94^{\mathrm{b}}$ & $27.21^{\mathrm{c}}$ & $5.06^{\mathrm{c}}$ \\
\hline 8.5 & $23.44^{\mathrm{cd}}$ & $40.34^{\mathrm{cd}}$ & $8.19^{\mathrm{e}}$ & $13.79^{\mathrm{b}}$ & $23.73^{\mathrm{bc}}$ & $4.82^{\mathrm{c}}$ \\
\hline 9.0 & $23.71^{\mathrm{cd}}$ & $38.28^{\mathrm{c}}$ & $8.66^{\mathrm{e}}$ & $13.17^{\mathrm{b}}$ & $21.27^{\mathrm{b}}$ & $4.81^{\mathrm{c}}$ \\
\hline 9.5 & $21.74^{\mathrm{c}}$ & $39.87^{\mathrm{c}}$ & $6.65^{\mathrm{d}}$ & $11.44^{\mathrm{b}}$ & $20.98^{\mathrm{b}}$ & $3.50^{\mathrm{b}}$ \\
\hline 10.0 & $23.81^{\mathrm{cd}}$ & $41.15^{\mathrm{cd}}$ & $6.56^{\mathrm{d}}$ & $11.90^{\mathrm{b}}$ & $20.58^{\mathrm{b}}$ & $3.28^{\mathrm{b}}$ \\
\hline
\end{tabular}

* Means followed by the same letters in columns did not differ significantly at $p<0.05$ according to the Duncan test 

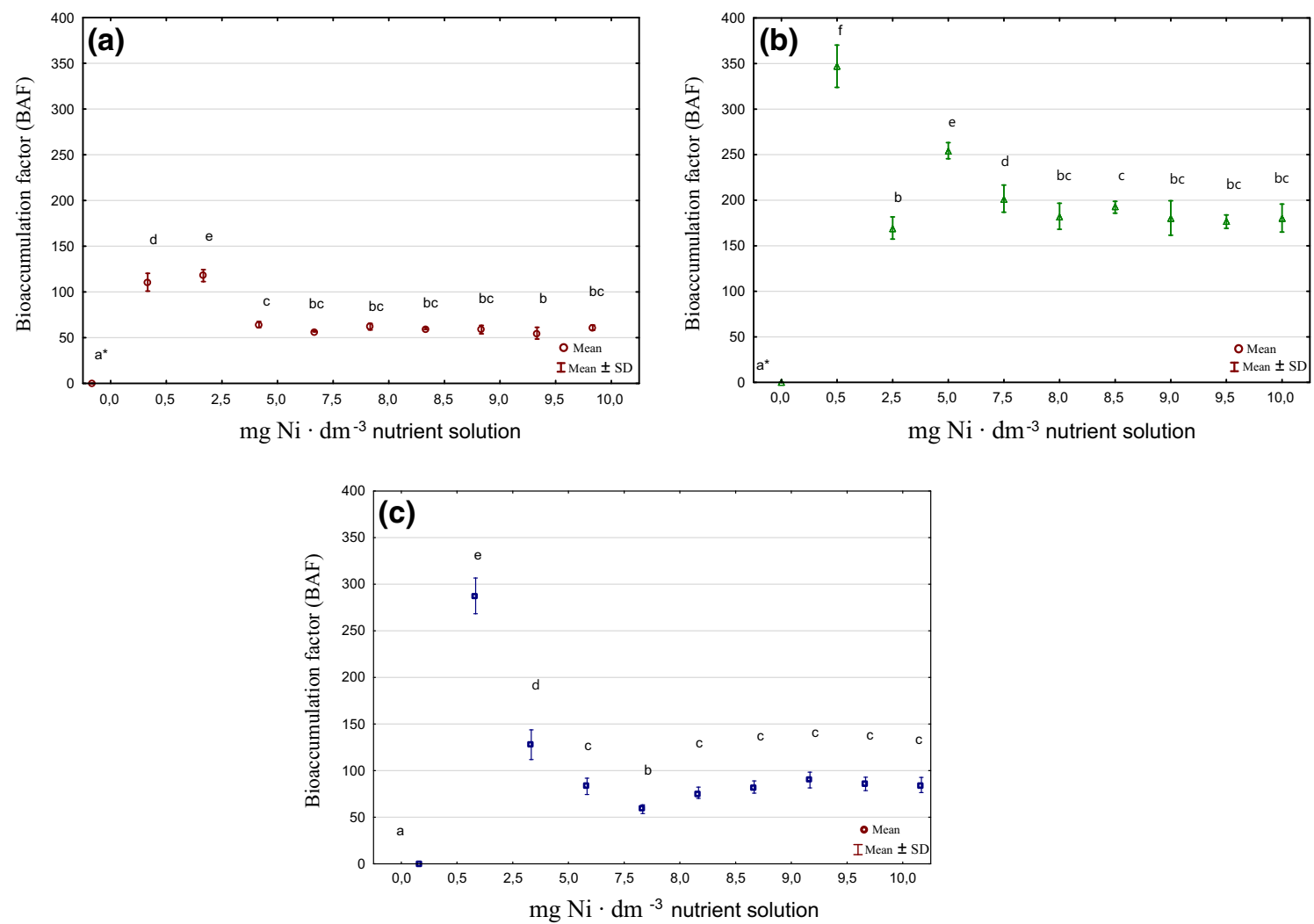

Fig. 4 Values of nickel bioaccumulation factor (BAF) in the aboveground parts of maize (a), field bean (b) and lettuce (c). Means followed by the same letters in columns did not differ significantly at $p<0.05$ according to the Duncan test

A toxic effect of nickel on plants observed in the presented investigations was visible as leaf chloroses, deformation of the aboveground parts and roots. According to Rathor et al. (2014) and Hussain et al. (2013), the main symptoms of toxic effect of nickel are: chlorosis of leaves or their yellowing followed by tissue necrosis. The other symptoms comprise deformations of various plant parts, inhibition of elongation growth of roots and aboveground parts or even necrosis of the whole plants (Brown et al. 1987; Madhaiyan et al. 2007).

Detailed studies on metal transformation from the soil to the plants and translocation to the aboveground parts allow to determine the abilities of individual plant species to accumulate heavy metals and therefore to identify them as potential phytoremediators (Maestri et al. 2010; Wei et al. 2008; Yusulf et al. 2011). According to Ogunkunle et al. (2014), Ghosh and Singh (2005), and Marchiol et al. (2004), values of TF and BAF are key parameters of the evaluation of plant ability for hyperaccumulation of the elements and determining their availability in the environment. Plant phytoremediation potentials are greatly diversified. Plants may reveal ability to accumulate only selected metals or absorb them at their synergic impact on the environment (Eapen and D'Souza 2005; McGrath et al.
2002). According to Peško and Král'ová' (2014) and Panwar et al. (2002) the ability to accumulate nickel may be diversified even within one species. The above-quoted authors stated a considerable diversification between the values of nickel BAF for two cultivars of Brassica napus cultivated under hydroponic conditions.

From the practical point of view, weighted average metal content in dry mass of plant aboveground parts, removed from the field at crop harvest, is the most important for the soil phytoremediation (Farrag et al. 2012; Sood et al. 2012). In their research on various crops abilities for nickel accumulation, Giordani et al. (2005) indicated a higher potential of spinach for this metal uptake $\left(65 \mathrm{~g} \mathrm{Ni}^{-1}\right.$ ton $\left.^{-1}\right)$ in comparison with cabbage, barley, sorghum or beans. In authors' own research, field bean and lettuce revealed almost twice higher efficiency in nickel removal in comparison with maize. Almost over $200 \mathrm{~g} \mathrm{Ni}$ was taken up with each ton of these plants dry mass. Such large uptake of nickel may be justified by this element occurrence in the nutrient solution in the directly bioavailable form.

Toxic effect of nickel on plants among others relies on causing oxidation stress through inhibiting the activity of superoxide dismutase (SOD), ascorbate peroxidase (APX) 
or glutathione reductase (GR) or reduction of transpiration and closing of stomata (Gajewska and Skłodowska 2005; Lu et al. 2010; Hussain et al. 2013). The effect of plant exposure to toxic contents of nickel in the environment may be also their growth inhibition and drying of leaves, as well as diminished yield (Gonnelli et al. 2001; Sarma 2011). Investigations of Giordani et al. (2005) point to no response in the form of a depression in bean yield (Fabaceae) cultivated on the soil contaminated with increasing doses of nickel (between 0 and $600 \mathrm{mg} \mathrm{Ni} \mathrm{kg}^{-1}$ of soil). The authors quoted above did not observe a reduction in barley yielding, either (Poaceae) under the influence of increasing doses of nickel. Rathor et al. (2014) assessed nickel contents, similar to presented in this paper, in maize cultivated under hydroponic conditions at nickel concentrations of 0 and $10.0 \mathrm{mg} \mathrm{Ni} \mathrm{dm}{ }^{-3}$ of nutrient solution, whereas at higher concentrations $\left(20-40 \mathrm{mg} \mathrm{Ni} \mathrm{dm}^{-3}\right)$ the authors registered an increase in this element concentrations both in the aboveground parts and roots. Increasing nickel contents in maize with subsequent doses of this component in the nutrient solution was accompanied by diminishing plant yield.

Natural phytoremediators should be characterised by a developed root system, fast growth, big production of biomass, tolerance to contamination and ability to accumulate several pollutants simultaneously (Luo et al. 2006; Jabeen et al. 2009). In the populations of plants that hyperaccumulate heavy metals, the mechanisms connected with absorption of these element ions from the soil, their transport to the aboveground parts and finally with their detoxification and compartmentation in shoots are more effective than the same processes in the populations which are not hyperaccumulators (Boyd and Jaffré 2009; Chaney et al. 2007; Hseu et al. 2010).

According to the criteria presented by Subhashini and Swamy (2013) and Marchiol et al. (2004), the hyperaccumulators and phytoremediators are the plant species for which: values of metal TF (ratio of metal content in the shoots and roots) are higher than 1, values of metal bioaccumulation in the aboveground parts (ratio of metal concentration in the shoots and nutrient solution) are bigger than 1, heavy metal content between 10 and 500 times higher than in the other plants growing in the same environment, concentrations of copper, lead, nickel, chrome on the level of over $1000 \mathrm{mg} \mathrm{kg}^{-1}$, or more than $100 \mathrm{mg} \mathrm{kg}^{-1}$ cadmium content, or zinc content more than $10,000 \mathrm{mg} \mathrm{kg}^{-1}$. When the concentrations of metal in the aboveground parts are lower than in roots, the plant is classified as a heavy metal excluder (Ahmad et al. 2007; Boularbah et al. 2006; Wang et al. 2005). On the other hand, in the indicator plants metal content is approximate to the concentrations in soil or in their growth environment. Assuming the criteria presented in this paper, the tested plants should be classified into heavy metal excluders. The obtained results allow to assess the studied species regarding the tolerance to high concentrations of nickel in the substratum and determine the level of its toxicity. Maize turned out to be the plant most sensitive to nickel excess in the substratum, whereas lettuce proved the most tolerant.

\section{Conclusions}

The yield of test plants depends on the analysed plant species, analysed plant part and nickel concentrations in the nutrient solution. Increasing doses of nickel doses in the nutrient solution cause a decrease in yield of maize, an field bean. In case of lettuce, an opposite dependence is noted, i.e. increase in yields under the influence of growing nickel doses in the nutrient solution. Nickel content in the aboveground parts of field bean and lettuce was almost twice higher in comparison with the contents registered in maize. Nickel was accumulated mainly in the roots of test plants. The highest values of TF characterised lettuce plants, almost twice lower values of the TF were noted for maize plants and the lowest for field bean. On the basis of the analysis of nickel CI it may be concluded that from among the tested plants, field bean revealed the greatest tendency for counteracting nickel accumulation in the shoots. From among the analysed test plants, the highest values of nickel BAF characterised field bean, whereas the lowest were noted for maize. Considering the test plant species, maize revealed the greatest nickel uptake from the nutrient solution, which is due to a big yielding potential of this plant. Lettuce is the most tolerant to increasing nickel doses among the analysed species, whereas maize is the most sensitive.

Author contribution statement Jacek Antonkiewicz: literature search, study design, data collection, data analysis, data interpretation, writing. Czesława Jasiewicz: literature search, study design, data interpretation, writing. Małgorzata Koncewicz-Baran: literature search, figures, tables, data analysis, data interpretation, writing. Renata Sendor: study design, data collection, data analysis.

Acknowledgments The research results carried out within the subject No. 3101 were financed from the subsidy for science granted by the Polish Ministry of Science and Higher Education.

Open Access This article is distributed under the terms of the Creative Commons Attribution 4.0 International License (http://crea tivecommons.org/licenses/by/4.0/), which permits unrestricted use, distribution, and reproduction in any medium, provided you give appropriate credit to the original author(s) and the source, provide a link to the Creative Commons license, and indicate if changes were made. 


\section{References}

Ahmad MSA, Ashraf M (2011) Essential roles and hazardous effects of nickel in plants. Rev Environ Contam Toxicol 214:125-167. doi:10.1007/978-1-4614-0668-6_6

Ahmad MSA, Hussain M, Sadding R (2007) Mungbean: a nickel indicator, accumulator or excluder? Bull Environ Contam Toxicol 78:319-324. doi:10.1007/s00128-007-9182-y

Bluskov S, Arocena JM, Omotoso OO, Young JP (2005) Uptake, distribution, and speciation of chromium in Brassica juncea. Int $\mathrm{J}$ Phytoremediation 7(2):153-165. doi:10.1080/16226510590950441

Boularbah A, Schwartz C, Bitton G, Aboudrar W, Ouhammou A, Morel JL (2006) Heavy metal contamination from mining sites in South Morocco: 2. Assessment of metal accumulation and toxicity in plants. Chemosphere 63:811-817. doi:10.1016/j. chemosphere.2005.07.076

Boyd RS (2004) Ecology of metal hyperaccumulation. New Phytologist 162:563-567. http://onlinelibrary.wiley.com/doi/10.1111/j. 1469-8137.2004.01079.x/epdf

Boyd RS, Jaffré T (2009) Elemental concentrations of eleven new caledonian plant species from serpentine soils: elemental correlations and leaf-age effects. Northeastern Nat 16(5):93-110. doi: $10.1656 / 045.016 .0508$

Brown PH, Welch RM, Cary EE (1987) Nickel: a micronutrient essential for higher plants. Plant Physiol 85:801-803. doi: 10.1104/pp.85.3.801.http://www.plantphysiology.org/content/ 85/3/801.full.pdf + html

Chaney RL, Angle JS, Broadhurst CL, Peters CA, Tappero RV, Sparks DL (2007) Improved understanding of hyperaccumulation yields commercial phytoextraction and phytomining technologies. J Environ Qual 36(5):1429-1443. doi:10.2134/ jeq2006.0514

Chen C, Huang D, Liu J (2009) Functions and toxicity of nickel in plants: recent advances and future prospects. Clean Soil Air Water 37:304-313. doi:10.1002/clen.200800199

Conesa HM, Faz A, Arnaldos R (2006) Heavy metal accumulation and tolerance in plants from mine tailings of the semiarid Cartagena-La Union mining district (SE Spain). Sci Total Environ 366:1-11. doi:10.1016/j.scitotenv.2005.12.008

Cunningham SD, Berti WR, Huang JW (1995) Phytoremediation of contaminated soils. Trends Biotechnol 13(9):393-397. doi:10. 1016/S0167-7799(00)88987-8

Eapen S, D'Souza SF (2005) Prospects of genetic engineering of plants for phytoremediation of toxic metals. Biotechnol Adv 23(2):97-114. doi:10.1016/j.biotechadv.2004.10.001

Farrag K, Senesi N, Rovira PS, Brunetti G (2012) Effects of selected soil properties on phytoremediation applicability for heavy-metalcontaminated soils in the Apulia region, Southern Italy. Environ Monit Assess 184:6593-6606. doi:10.1007/s10661-011-2444-5

Gajewska E, Skłodowska M (2005) Antioxidative responses and proline level in leaves and roots of pea plants subjected to nickel stress. Acta Physiol Plant 27(3B):329-339. doi:10.1007/s11738-005-0009-3

Ghosh M, Singh SP (2005) A review on phyto-remediation of heavy metals and utilization of its byproducts. Appl Ecol Environ Res 3(1):1-19. doi:10.15666/aeer/0301_001018

Giordani C, Cecchi S, Zanchi C (2005) Phytoremediation of soil polluted by nickel using agricultural crops. Environ Manage 36(5):675-681. doi:10.1007/s00267-004-0171-1

Gonnelli C, Calardi F, Gabbrielli R (2001) Nickel and copper tolerance and toxicity in three Tuscan populations of Silene paradoxa. Physiol Plant 113:507-514. doi:10.1034/j.1399-3054. 2001.113049.x

Guo Y, Marschner H (1995) Uptake, distribution, and binding of cadmium and nickel in different plant species. J Plant Nutr 18(12):2691-2706. doi:10.1080/01904169509365094
Hseu ZY, Su SW, Lai HY, Guo HY, Chen TC, Chen ZS (2010) Remediation techniques and heavy metal uptake by different rice varieties in metal-contaminated soils of Taiwan: new aspects for food safety regulation and sustainable agriculture. Soil Sci Plant Nutr 56:31-52. doi:10.1111/j.1747-0765.2009.00442.x

Hussain MB, Ali S, Azam A, Hina S, Ahsan M, Farooq BA, Bharwana SA, Gill MB (2013) Morphological, physiological and biochemical responses of plants to nickel stress: a review. Afr J Agric 8(17):1596-1602. doi:10.5897/AJAR12.407

Jabeen R, Ahmad A, Iqbal M (2009) Phytoremediation of heavy metals: physiological and molecular mechanisms. Bot Rev 75:339-364. doi:10.1007/s12229-009-9036-x

Kidd P, Barcelo J, Bernal MP, Navari-Izzo F, Poschenrieder C, Shilev S, Clemente R, Monterroso C (2009) Trace element behavior at the root-soil interface: implications in phytoremediation. Environ Exp Bot 67(1):243-259. doi:10.1016/j.envexpbot.2009.06.013

Kim S, Takahashi M, Higuchi K, Tsunoda K, Nakanishi H, Yoshimura E, Mori S, Nishizawa NK (2005) Increased nicotianamine biosynthesis confers enhanced tolerance of high levels of metals, in particular nickel, to plants. Plant Cell Physiol 46(11):1809-1818. doi:10.1093/pcp/pci196

Krueger E, Darland J, Goldyn S, Swanson R, Lehmann R, Shepardson S, Karpovich D (2013) Water leaching of chelated $\mathrm{Pb}$ complexes from post-phytoremediation biomass. Water Air Soil Pollut 224:1615. doi:10.1007/s11270-013-1615-0

Kusznierewicz B, Bączek-Kwinta R, Bartoszek A, Piekarska A, Huk A, Manikowska A, Antonkiewicz J, Namieśnik J, Konieczka P (2012) The dose-dependent influence of zinc and cadmium contamination of soil on their uptake and glucosinolate content in white cabbage (Brassica Oleracea var. Capitata F. Alba). Environ Toxicol Chem 31(11):2482-2489. doi:10.1002/etc.1977

Lu Y, Li X, He M, Zhao X, Liu Y, Cui Y, Pan Y, Tan H (2010) Seedlings growth and antioxidative enzymes activities in leaves under heavy metal stress differ between two desert plants: a perennial (Peganum harmala) and an annual (Halogeton glomeratus) grass. Acta Physiol Plant 32:583-590. doi:10.1007/ s11738-009-0436-7

Luo C, Shen Z, Li X, Baker AJM (2006) Enhanced phytoextraction of $\mathrm{Pb}$ and other metals from artificially contaminated soils through the combined application of EDTA and EDDS. Chemosphere 63:1773-1784. doi:10.1016/j.chemosphere.2005.09.050

Ma Y, Rajkumar M, Freitas H (2009) Improvement of plant growth and nickel uptake by nickel resistant-plant-growth promoting bacteria. J Hazard Mater 166(2-3):1154-1161. doi:10.1016/j. jhazmat.2008.12.018

Mackay D, Fraser A (2000) Bioaccumulation of persistent organic chemicals: mechanisms and models. Environ Pollut 110:375-391 (S0269-7491(00)00162-7)

Madhaiyan M, Poonguzhali S, Sa T (2007) Metal tolerating methylotrophic bacteria reduces nickel and cadmium toxicity and promotes plant growth of tomato (Lycopersicon esculentum L). Chemosphere 69(2):220-228

Maestri E, Marmiroli M, Visioli G, Marmiroli N (2010) Metal tolerance and hyperaccumulation: costs and trade-offs between traits and environment. Environ Exp Bot 68:1-13. doi:10.1016/j. envexpbot.2009.10.011

Marchiol L, Sacco P, Assolari S, Zerbi G (2004) Reclamation of polluted soil: phytoremediation potential of crop-related Brassica Species. Water Air Soil Pollut 158:345-356

McGrath SP, Zhao FJ, Lombi E (2002) Phytoremediation of metals, metalloids, and radionuclides. Adv Agron 75:1-56. doi:10.1016/ S0065-2113(02)75002-5

Meers E, Ruttens A, Hopgood M, Lesage E, Tack FMG (2005) Potential of Brassic rapa, Cannabis sativa, Helianthus annuus and Zea mays for phytoextraction of heavy metals from 
calcareous dredged sediment derived soils. Chemosphere 61:561-572. doi:10.1016/j.chemosphere.2005.02.026

Miguel B, Edell A, Edson Y, Edwin P (2013) A phytoremediation approach using Calamagrostis ligulata and Juncus imbricatus in Andean wetlands of Peru. Environmental monitoring assessment 185:323-334. doi:10.1007/s10661-012-2552-x

Murphy A, Tayz L (1995) A new vertical mesh transfer technique for metal-tolerance studies in Arabidopsis (ecotypic variation and copper-sensitive mutants). Plant Physiol 108:29-38. doi:10. 1104/pp.108.1.29

Neugschwandtner RW, Tlustoš P, Komárek M, Száková J (2008) Phytoextraction of $\mathrm{Pb}$ and $\mathrm{Cd}$ from a contaminated agricultural soil using different EDTA application regimes: laboratory versus field scale measures of efficiency. Geoderma 144:46-454. doi:10.1016/j.geoderma.2007.11.021

Ogunkunle CO, Fatoba PO, Oyedeji AO, Awotoye OO (2014) Assessing the heavy metal transfer and translocation by Sida acuta and Pennisetum purpureum for phytoremediation purposes. Albanian J Agric Sci 13(1):71-80

Ostrowska A, Gawliński S, Szczubiałka Z (1991) Methods of analysis and assessment of soil and plant properties. A catalgoue. Institute of Environmental Protection-National Research Institute, Warsaw, pp 334

Padmavathiamma P, Li LY (2007) Phytoremediation technology: hyperaccumulation metals in plants. Water Air Soil Pollut 184(1-4):105-126. doi:10.1007/s11270-007-9401-5

Panwar BS, Ahmed KS, Mittal SB (2002) Phytoremediation of nickel-contaminated soils by Brassica species. Environ Dev Sustain 4(1):1-6. doi:10.1023/A:1016337132370

Park JH, Lamb D, Paneerselvam P, Choppala G, Bolan N, Chung JW (2011) Role of organic amendments on enhanced bioremediation of heavy metal (loid) contaminated soils. J Hazard Mater 185:549-574. doi:10.1016/j.jhazmat.2010.09.082

Peško M, Král'ová K (2014) Physiological response of two Brassica napus $L$. cultivars to nickel treatment. Ecol Chem Eng $S$ 21(1):25-34. doi:10.2478/eces-2014-0002

Ramamurthy AS, Memarian R (2012) Phytoremediation of mixed soil contaminants. Water Air Soil Pollut 223:511-518. doi:10.1007/ s11270-011-0878-6

Rascio N, Navari-Izzo F (2011) Heavy metal hyperaccumulating plants: how and why do they do it? And what makes them so interesting? Plant Sci 180(2):169-181. doi:10.1016/j.plantsci. 2010.08.016

Rathor G, Chopra N, Adhikari T (2014) Effect of variation in nickel concentration on growth of maize plant: A comparative overview for pot and hoagland culture Res. J Chem Sci 4(10): 30-32. http://www.isca.in, http://www.isca.me

Robinson BH, Lombi E, Zhao FJ, McGrath SP (2003) Uptake and distribution of nickel and other metals in the hyperaccumulator
Berkheya coddii. New Phytol 158:279-285. doi:10.1046/j.14698137.2003.00743.x

Ruus A, Schaanning M, Øxnevad S, Hylland K (2005) Experimental results on bioaccumulation of metals and organic contaminants from marine sediments. Aquat Toxicol 72(3):273-292. doi:10. 1016/j.aquatox.2005.01.004

Sarma H (2011) Metal hyperaccumulation in plants: a review focusing on phytoremediation technology. J Environ Sci Technology 4(2):118-138. doi:10.3923/jest.2011.118.138

Seregin IV, Kozhevnikova AD (2006) Physiological role of nickel and its toxic effects on higher plants. Russ J Plant Physiol 53(2):257-277. doi:10.1134/S1021443706020178

Sood A, Uniyal PL, Prasanna R, Ahluwalia AS (2012) Phytoremediation potential of aquatic macrophyte, Azolla. Environ Monit Assess 41:122-137. doi:10.1007/s13280-011-0159-Z

Subhashini V, Swamy AVVS (2013) Phytoremediation of Pb and Ni contaminated soils using Catharanthus roseus (L.). Univers J Environ Res Technol 3(4):465-472. http://www.environmental journal.org/3-4/ujert-3-4-7.pdf

Tank N, Saraf M (2009) Enhancement of plant growth and decontamination of nickel-spiked soil using PGPR. J Basic Microbiol 49(2):195-204. doi:10.1002/jobm.200800090

Wang Y, Stauffer C, Keller C, Greger M (2005) Changes in $\mathrm{Hg}$ fractionation in soil induced by willow. Plant Soil 275:67-75. doi:10.1007/s11104-004-6108-x

Wei S, Teixeira da Silva JA, Zhou Q (2008) Agroimproving method of phytoextracting heavy metal contaminated soil. J Hazard Mater 150:662-668. doi:10.1016/j.jhazmat.2007.05.014

Xiang W, Xiao Y, Rengel Z (2009) Phytoremediation facilitates removal of nitrogen and phosphorus from eutrophicated water and release from sediment. Environ Monit Assess 157:277-285. doi:10.1007/s10661-008-0534-9

Yang X, Baligar VC, Martens DC, Clark RB (1996) Plant tolerance to nickel toxicity: II nickel effects on influx and transport of mineral nutrients in four plant species. J Plant Nutr 19(2):265-279. doi:10.1080/01904169609365121

Yang X, Feng Y, He Z, Stoffell PJ (2005) Molecular mechanisms of heavy metal hyperaccumulation and phytoremediation. J Trace Elem Med Biol 18:339-353. doi:10.1016/j.jtemb.2005.02.007

Yusulf M, Fariduddin Q, Hayat S, Ahmad A (2011) Nickel: an overview of uptake, essentiality and toxicity in plants. Bull Environ Contam Toxicol 86:1-17. doi:10.1007/s00128-010-0171-1

Zhao J, Shi G, Yuan Q (2008) Polyamines content and physiological and biochemical responses to ladder concentration of nickel stress in Hydrocharis dubia (B1.) backer leaves. Biometals 21:665-674. doi:10.1007/s10534-008-9151-x 